Elena Masnevaité

Katedra Prawa Publicznego

Uniwersytet Wileński

\title{
GRANICE KOMPETENCJI GŁÓWNEJ KOMISJI WYBORCZEJ REPUBLIKI LITEWSKIEJ W PROCESIE ZMIANY KONSTYTUCJI REPUBLIKI LITEWSKIEJ (NA PRZYKŁADZIE REFERENDUM Z DNIA 24 CZERWCA 2014 R.)
}

Konstytucja Republiki Litewskiej ${ }^{1}$ (dalej: Konstytucja) zgodnie z określonym w niej trybem wprowadzenia zmian jest zaliczana do kategorii sztywnych. Na Litwie można wyróżnić dwa rodzaje przepisów konstytucyjnych: te, które można zmienić na drodze referendum oraz te, które można zmienić na drodze ustawy.

Główna Komisja Wyborcza Republiki Litewskiej (dalej: Główna Komisja Wyborcza) posiada uprawnienia do uczestniczenia w procesie zmiany Konstytucji dopiero wówczas, gdy zmiana Konstytucji następuje na drodze referendum, chociaż w Konstytucji expressis verbis o tym się nie mówi. Spowodowało to, że podczas rozpatrywania przez Sąd Konstytucyjny Republiki Litewskiej (dalej: Sąd Konstytucyjny) kwestii dotyczącej granic kompetencji Głównej Komisji Wyborczej w procesie organizacji i przeprowadzenia referendum dotyczącego zmian Konstytucji, zdania sędziów Sądu Konstytucyjnego w sprawie tego, czy Główna Komisja Wyborcza posiada jakiekolwiek należyte wynikające z Konstytucji kompetencje do wzięcia udziału w tym procesie, od samego początku były podzielone.

Na Litwie wniosek o wprowadzenie zmian lub uzupełnień do Konstytucji ma prawo złożyć nie mniej niż 300000 obywateli posiadających czynne prawo wyborcze. Od odzyskania niepodległości w 1990 r. było około dwudziestu takich inicjatyw, być może nieco mniej², aczkolwiek tylko jedna

\footnotetext{
${ }^{1}$ „Valstybės žinios” 1992, Nr 33-1014 (z późniejszymi zmianami i uzupełnieniami).

${ }^{2} \mathrm{O}$ inicjatywie przeprowadzenia referendum zob. więcej na stronie internetowej Głównej Komisji Wyborczej: www.vrk.lt (dostęp 10.11.2014).
} 
z nich została zrealizowana - inicjatywa o zmianie art. 9, 47 i 147, znana jako referendum w sprawie zakazu sprzedaży ziemi obcokrajowcom. Referendum to zorganizowano w dniu 29 czerwca 2014 r. i wywołało prawdziwe poruszenie społeczne, prawne i polityczne.

Nie powinno to budzić zdziwienia, jeśli uwzględni się fakt, że proponowano zmniejszyć do 100000 liczbę wyborców posiadających prawo do wystąpienia $\mathrm{z}$ wnioskiem o przeprowadzenie referendum, występujących z inicjatywą wprowadzenia zmian lub uzupełnień w Konstytucji oraz uchwalenia, iż ziemia i nieruchomości tego rodzaju stanowią wyłączną własność obywateli Republiki Litewskiej oraz państwa, niezależnie od tego, że z dniem 1 maja 2014 r. przestał obowiązywać wyjątek w sprawie zakazu nabywania gruntów rolnych przez podmioty zagraniczne.

Należy przypomnieć, że niezależnie od tego, iż art. 47 Konstytucji regulujący sprawy własności ziemi może być zmieniony na drodze legislacyjnej, w tym konkretnym przypadku wszystkie zmiany do Konstytucji proponowano wprowadzić na drodze referendum, ponieważ zostały one przedstawione in corpore, jako pakiet, chociaż taka „zbiorowa” praktyka (gdy proponowano jednocześnie zmienić przepisy, które nie spełniają warunku integralności ich treści, ponieważ powinny być zmienione w odmiennym trybie: niektóre - na drodze referendum, zaś pozostałe - na drodze parlamentarnej) nie jest zgodna z wytycznymi o ogólnokrajowych referendach konstytucyjnych Europejskiej Komisji na Rzecz Demokracji przez Prawo (Komisji Weneckiej), uchwalonych w dn. 6-7 lipca 2001 r. podczas 47 sesji plenarnej ${ }^{3}$.

Inicjatywa w sprawie zmian w Konstytucji została zarejestrowana przez Główną Komisję Wyborczą na początku sierpnia $2013 \mathrm{roku}^{4}$. Jak podaje Departament Prawa Kancelarii Sejmu Republiki Litewskiej ${ }^{5}$ (dalej: Sejm) oraz Ministerstwo Sprawiedliwości Republiki Litewskiej ${ }^{6}$, pierwotny projekt złożony przez grupę inicjatywną zawierał nieścisłości w zakresie formy, struktury, treści i języka, aczkolwiek w żadnym z pism nadesłanych przez powyż-

${ }^{3}$ Guidelines for Constitutional Referendums at National Level (adopted by the Venice Commission at its $47^{\text {th }}$ Plenary Meeting, Venice, 6-7 July 2001), http://www.venice.coe.int/ webforms/documents/CDL-INF(2001)010-e.aspx (dostęp 11.11.2014).

${ }^{4}$ Wniosek z dn. 1 września 2013 r. o zarejestrowaniu przez Główną Komisję Wyborczą grupy inicjatywnej obywateli Republiki Litewskiej występującej z propozycją wprowadzenia zmian w ustawie konstytucyjnej drogą referendum (dn. 2 września 2013 r., reg. Nr 1-1564(2.10)).

${ }^{5}$ Pismo Departamentu Prawa Kacelarii Sejmu Republiki Litewskiej Nr S-2013-6881 „0 ogłoszeniu referendum w sprawie projektu ustawy zgłoszonego przez grupę inicjatywną" z dn. 7 sierpnia $2013 \mathrm{r}$.

6 Pismo Ministerstwa Sprawiedliwości Republiki Litewskiej Nr (1.11.)-7R-5940 „O ogłoszeniu referendum w sprawie projektu ustawy zgłoszonego przez grupę inicjatywną" z dn. 14 sierpnia $2013 \mathrm{r}$. 
sze instytucje nawet nie wspomniano o tym, że niektóre poprawki proponowane do wprowadzenia na drodze referendum są sprzeczne lub mogą być sprzeczne ze zobowiązaniami Litwy wobec Unii Europejskiej, a tym samym z Konstytucją.

Kwestia ta po raz pierwszy została poruszona przez samych członków Głównej Komisji Wyborczej podczas obrad Głównej Komisji Wyborczej, na których omawiano sprawę zarejestrowania grupy inicjatywnej, która wystąpiła z wnioskiem o przeprowadzenie referendum ${ }^{7}$.

Zostało również zadane pytanie, dlaczego zdaniem grupy inicjatywnej jest konstytucyjnie uzasadnione pozbawienie wszystkich osób prawnych prawa do własności ziemi oraz podobnego rodzaju nieruchomości. Niezależnie od wszystkich przedstawionych argumentów, członkowie Głównej Komisji Wyborczej nie zyskali poparcia i grupa inicjatywna została zarejestrowana.

Nieco później, tj. w dn. 24 stycznia 2014 r. w sprawie możliwości wprowadzenia zmian w Konstytucji bez przestrzegania zobowiązań Litwy wobec Unii Europejskiej wyraźnie wypowiedział się Sąd Konstytucyjny8.

Po pierwsze Sąd Konstytucyjny wyjaśnił, że przepisy art. 1 i 2 ustawy konstytucyjnej „O członkostwie Republiki Litewskiej w Unii Europejskiej” mogą być zmienione lub uchylone tylko na drodze referendum, ponieważ zawierają podstawy konstytucyjne członkostwa Republiki Litewskiej w Unii Europejskiej, bez utrwalenia których w Konstytucji, Republika Litewska nie mogłaby być pełnoprawnym członkiem Unii Europejskiej.

Następnie Sąd Konstytucyjny przypomniał, że geopolityczna orientacja państwa litewskiego oznacza inter alia członkostwo Republiki Litewskiej w Unii Europejskiej oraz konieczność wykonywania zobowiązań międzynarodowych wynikających z tego członkostwa, a także podkreślił, że przez wprowadzenie poprawek do Konstytucji nie można powodować naruszenia przepisów Konstytucji, równowagi wartości w niej utrwalonych.

Ostatecznie Sąd Konstytucyjny stwierdził, że bez unieważnienia w trybie określonym w Konstytucji wspomnianych powyżej podstaw konstytucyjnych członkostwa Republiki Litewskiej w Unii Europejskiej zatwierdzonych w art. 1 i 2 aktu konstytucyjnego „0 członkostwie Republiki Litewskiej w Unii Europejskiej", inaczej mówiąc, bez wystąpienia z Unii Europejskiej, nie mogą być wprowadzone do Konstytucji poprawki, które zaprzeczają

${ }^{7}$ Nagranie posiedzenia Głównej Komisji Wyborczej Republiki Litewskiej z dn. 22 sierpnia 2013 r., http://www.penki.lt/ott/vrk_arch.aspx?stream=vrk_2013-08-22_high.flv (dostęp 3.11.2014).

${ }^{8}$ Orzeczenie Sądu Konstytucyjnego Republiki Litewskiej z dn. 24 stycznia 2014 r. // TAR, 2014, Nr 478.

${ }^{9}$ „Valstybės žinios” 2004, s. 111-4123. 
zobowiązaniom Republiki Litewskiej wobec Unii Europejskiej. W ten sposób zostało sformułowane jedno z merytorycznych ograniczeń dotyczących wprowadzenia zmian w Konstytucji ${ }^{10}$.

Aczkolwiek Sąd Konstytucyjny w tym orzeczeniu nie rozwiązał jednego problemu, tj. nie wypowiedział się w sprawie tego, w czyich kompetencjach leży wydanie wniosku, że proponowane zmiany lub uzupełnienia w Konstytucji są sprzeczne z Konstytucją. Sąd Konstytucyjny Litwy nie sprawuje kontroli nad konstytucyjnością przed uchwaleniem ustawy (również nie może działać ex officio), natomiast granice kompetencji Głównej Komisji Wyborczej w tej sprawie nigdzie nie zostały wyraźnie zdefiniowane. Można stwierdzić, że dopóki w dn. 11 lipca 2014 r. nie interweniował Sąd Konstytucyjny ${ }^{11}$, z Ustawy Republiki Litewskiej o Referendum ${ }^{12}$ można było wywnioskować, że w procesie organizacji i przeprowadzenia referendum posiada ona kompetencje o charakterze bardziej technicznym (s. 20), a mianowicie do jej obowiązków należy:

1) rejestrowanie grupy inicjatywnej;

2) wydanie grupie inicjatywnej formularzy do zbierania podpisów obywateli;

${ }^{10}$ W Orzeczeniu Sądu Konstytucyjnego z dn. 24 stycznia 2014 r. zostały sformułowane również inne ograniczenia merytoryczne dotyczące wprowadzenia zmian w Konstytucji:

- nie można wprowadzać do Konstytucji takich poprawek, które są sprzeczne chociaż z jedną z fundamentalnych wartości konstytucyjnych Republiki Litewskiej zatwierdzonych w Konstytucji jako dobro całego społeczeństwa - niepodległością państwa, demokracją, republiką, prawami i wolnościami człowieka o charakterze przyrodzonym, z wyjątkiem przypadku, gdy w trybie określonym w cz. 1 art. 148 Konstytucji może być zmieniony artykuł 1 Konstytucji i ustawy Konstytucyjnej „O Państwie Litewskim”, który stanowi część integralną Konstytucji oraz zmieniony artykuł 1 tej ustawy;

- nie można wprowadzać takich zmian do Konstytucji Republiki Litewskiej, które zaprzeczają przepisom aktu konstytucyjnego „O nieprzynależności Republiki Litewskiej do postsowieckich związków wschodnich”, z wyjątkiem przypadku, gdy odpowiednie przepisy tego aktu konstytucyjnego są zmieniane w tym samym trybie, jaki został określony w art. 2 Ustawy Konstytucyjnej „O Państwie Litewskim”;

- nie można wprowadzać takich zmian do Konstytucji, które zaprzeczają międzynarodowym zobowiązaniom Republiki Litewskiej (inter alia zobowiązaniom Republiki Litewskiej wobec NATO wynikającym z orientacji geopolitycznej państwa litewskiego, a jednocześnie zasadzie konstytucyjnej pacta sunt servanda, gdy nie rezygnuje się ze zobowiązań międzynarodowych w oparciu o normy prawa międzynarodowego;

- Sejm nie może wprowadzać takich poprawek do Konstytucji, które są sprzeczne z przepisami rozdziału I „Państwo Litewskie”, rozdziału XIV „Wprowadzenie zmian w Konstytucji"; na drodze referendum nie można wprowadzać takich poprawek w Konstytucji, które bez odpowiedniej zmiany przepisów rozdziału I „Państwo Litewskie”, rozdziału XIV „Wprowadzenie zmian w Konstytucji" ustanawiają sprzeczną regulację konstytucyjną w stosunku do tych rozdziałów.

${ }^{11}$ Orzeczenie Sądu Konstytucyjnego Litwy z dn. 11 lipca 2014 r. // TAR, 2014-07-11, Nr 10116.

12 „Valstybės žinios” 2002, Nr 64-2570. 
3) sprawdzenie i ustalenie, czy zostało zebranych ważnych 300 tys. podpisów;

4) powołanie komisji miejskich i rejonowych do przeprowadzenia referendum;

5) ustalenie wzorów kart do głosowania w referendum oraz innych dokumentów używanych podczas referendum, pakietów, wzorców i form pieczęci, zasad prawidłowego wypełnienia kart do głosowania oraz trybu ich wydrukowania;

6) zarządzanie państwowymi środkami finansowymi przeznaczonymi na cele referendum;

7) nadzór nad wykonaniem Ustawy o Referendum;

8) rejestrowanie przedstawicieli partii i obserwatorów przy GKW oraz wydanie im legitymacji;

9) rozpatrywanie skarg i podejmowanie decyzji w sprawie postanowień wydanych podczas przeprowadzenia referendum przez komisje miejskie, rejonowe, apilinkowe (przyp. tłum.: Apylinke (lit.) - jednostka podziału administracyjnego na Litwie, brak odpowiednika w języku polskim);

10) podsumowanie i ogłoszenie ostatecznych wyników referendum itd.

W oparciu o powyżej wymienione orzeczenie Sądu Konstytucyjnego, część członków Głównej Komisji Wyborczej (faktycznie grupa), nie zważając ani na brak wyraźnej regulacji prawnej, ani na tę okoliczność, że już prawie została zebrana niezbędna liczba podpisów obywateli (do dn. 29 stycznia 2014 r. Główna Komisja Wyborcza wyznaczyła termin na usunięcie niezbyt istotnych niedociągnięć ${ }^{13}$, a to oznacza, że zebrane podpisy obywateli zostały zweryfikowane), podjęła takie działania, by organizowanie referendum zostało przerwane ${ }^{14}$.

Podczas głosowania, które odbyło się w dniu 29 stycznia 2014 r. w sprawie ich inicjatywy, liczba głosów była równa. Na negatywną decyzję miała wpływ postawa przewodniczącego Komisji Wyborczej ${ }^{15}$.

${ }^{13}$ Np. Orzeczenie Głównej Komisji Wyborczej z dn. 14 stycznia 2014 r. Nr Sp-3 „W sprawie żądań obywateli o ogłoszeniu referendum”, „W sprawie kontroli Ustawy o zmianie art. 9, 47 i 147 Konstytucji Republiki Litewskiej”, TAR, 2014, Nr 2014-00244; Postanowienie Głównej Komisji Wyborczej z dn. 14 stycznia 2014 r. Nr Sp-12 „Odnośnie przeprowadzenia weryfikacji żądania obywateli ogłoszenia referendum w sprawie „Ustawy o zmianie art. 9, 47 i 147 Konstytucji Republiki Litewskiej”, TAR, 2014, Nr 2014-00328.

${ }^{14}$ Zaświadczenie członków Głównej Komisji Wyborczej z dn. 28 stycznia 2014 r. o zgodności inicjatywy obywatelskiej z dn. 22 sierpnia 2013 r. o przeprowadzeniu referendum w sprawie „Zmiany art. 9, 47 i 147 Ustawy Republiki Litewskiej o Konstytucji” z Konstytucją i zobowiązaniami wobec Unii Europejskiej.

${ }^{15}$ Nagranie wideo z obrad Głównej Komisji Wyborczej Republiki Litewskiej w dn. 28 stycznia 2014 r., http://www.penki.lt/ott/vrk_arch.aspx?stream=vrk_2014_01_29_high.flv/ (dostęp 11.11.2014). 
Po takim, nazwijmy to ekscesie, Głównej Komisji Wyborczej zarzucono próbę ograniczenia suwerenności Narodu, doczekała się ona gniewnych reakcji ze strony poszczególnych osób. Na przykład jeden z członków Głównej Komisji Wyborczej Rokas Stabingis podczas głośnego posiedzenia Głównej Komisji Wyborczej zadał pytanie: „Czy Suweren powinien przestrzegać przepisów Konstytucji?”, po czym otrzymał list z groźbami oraz propozycją

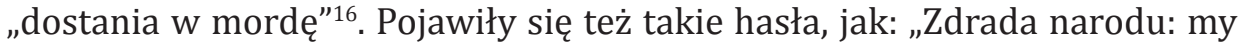
podejmiemy decyzje za was" ${ }^{17}$.

Podczas organizowania referendum w sprawie zakazu sprzedaży ziemi obcokrajowcom na Główną Komisję Wyborczą ciągle i na różne sposoby była wywierana presja ze strony różnych podmiotów.

Na przykład do Głównej Komisji Wyborczej (oraz do mediów) zwróciła się grupa populistycznie nastawionych posłów na Sejm ${ }^{18}$, którzy nie mogli nie zauważyć „zbyt gorliwej pracy członków GKW” [przyp. aut.: Głównej Komisji Wyborczej], którzy usiłowali „unieważnić listy z podpisami obywateli o przeprowadzenie referendum" złożone przez Grupę [przyp. aut.: Grupę inicjatywną], zachęcali do „zwrotu Suwerenowi jemu należnych praw i nie przeszkadzania, a pomagania obywatelom Litwy w budowaniu własnego państwa oraz społeczeństwa obywatelskiego".

Do Przewodniczącej Sejmu, frakcji, posłów, Głównej Komisji Wyborczej i, rzecz jasna, mediów w imieniu Grupy Helsińskiej na Litwie, stowarzyszenia „Bezpartyjny Ruch Demokratyczny”, Litewskiego Stowarzyszenia Obrony Praw Człowieka i Fundacji Obrony Praw Obywatelskich został wystosowany apel ${ }^{19}$, a Główną Komisję Wyborczą posądzono o przyczynienie się do tego, by jak najwięcej podpisów złożonych przez grupę inicjatywną było uznanych za nieważne, tak by referendum w sprawie zakazu sprzedaży ziemi obcokrajowcom nie zostało ogłoszone.

Później na podstawie wspomnianego powyżej oświadczenia okazało się, że w ten sposób Główna Komisja Wyborcza zajmuje się działalnością kolaboracyjną, ponieważ „[...] Litwa jest państwem granicznym UE. Jej granica państwowa przebiega wzdłuż państw nieprzyjaźnie nastawionych, w których systematycznie są prowadzone agresywne pod adresem Litwy manewry wojenne i obecnie wzdłuż granicy Litwy jest gromadzony nowy sprzęt

${ }^{16}$ Po głosowaniu w sprawie referendum, członek GKW doczekał się pogróżek „dostania w mordę", http://www.delfi.lt/news/daily/lithuania/po-balsavimo-del-referendumo-vrk-narys-sulauke-grasinimu-gauti-i-snuki.d?id=63885486/ (dostęp 4.11.2014).

17 http://www.respublika.lt/lt/naujienos/lietuva/lietuvos_politika/tautos_isdavyste_mes_ nuspresime_uz_jus/,print.1/ (prisijungta 2014 m. lapkričio 4 d.).

${ }^{18}$ Pismo z dn. 23 grudnia 2013 r. „W sprawie ogłoszenia referendum” (31 grudnia 2013 r., Nr rejestr.1-24(2.10)).

${ }^{19}$ Wniosek z dn. 24 grudnia 2013 r. „W sprawie inicjatywy obywateli o przeprowadzeniu referendum" (27 grudnia 2013 r., Nr. Rejestr. 1-2297(2.10)). 
wojskowy. Dlatego sprzedaż ziemi może być wykorzystana jako jedna z możliwości umocnienia się na terytorium Litwy, jako pretekst do wywołania konfliktów wojennych z państwami sąsiednimi i obrony nabytych posiadłości przy użyciu sił wojskowych [...]".

Wyrobione zdanie na temat Głównej Komisji Wyborczej w organizowanym referendum w sprawie zakazu sprzedaży ziemi obcokrajowcom miał np. jeden z sygnatariuszy Aktu Niepodległości Litwy ${ }^{20}$, który otwarcie zarzucił jej manipulowanie danymi i dokumentami, uprawianie samowoli i brak kompetencji, nadużywanie władzy i całkowity brak szacunku dla grupy inicjatywnej oraz dla wszystkich obywateli, którzy poparli inicjatywę ogłoszenia referendum przez złożenie podpisu.

Natomiast jeśli chodzi o nadgorliwych członków Głównej Komisji Wyborczej, po tym gdy referendum zostało przeprowadzone, okazało się, że mieli oni rację. Sąd Konstytucyjny w orzeczeniu z dn. 11 lipca 2014 r., rozważając, czy w Ustawie o Referendum w zdefiniowaniu kompetencji Głównej Komisji Wyborczej nie została powołana komisja legislacyjna, wyjaśnił, że Główna Komisja Wyborcza jest właśnie tym podmiotem, który pełni funkcje kontrolne i ma obowiązek niezarejestrowania takiej poprawki do Konstytucji, która nie przestrzega ograniczeń merytorycznych wynikających z Konstytucji. Zdaniem Sądu Konstytucyjnego takie kompetencje Głównej Komisji Wyborczej wynikają z konstytucyjnych zasad państwa prawnego, prymatu Konstytucji i odpowiedzialnego sprawowania władzy.

Poza tym Sąd Konstytucyjny podkreślił, że takie założenia Konstytucji, jak: „suwerenność należy do Narodu”, „najwyższą władzę suwerenną Naród sprawuje bezpośrednio” i "kwestie najważniejsze dla narodu i państwa są rozstrzygane na drodze referendum", nie mogą być interpretowane jedynie dosłownie i nie można ich absolutyzować, tj. nie należy ich rozumieć w ten sposób, że naród na drodze referendum może ustalić dowolną regulację prawną, nawet niezgodną z wymogami wynikającymi z Konstytucji, a także w samej Konstytucji. Czyli pytanie zadane przez członka Głównej Komisji Wyborczej Rokasa Stabingisa do członków grupy inicjatywnej było na czasie i na miejscu. Zwłaszcza że jeszcze w orzeczeniu z dn. 1 grudnia 1994 roku $^{21}$ Sąd Konstytucyjny stwierdził, że grupy inicjatywne w sprawie zorganizowania referendum nie mogą być utożsamiane z Narodem ani nie mogą przemawiać $\mathrm{w}$ jego imieniu.

${ }^{20}$ Konferencja prasowa sygnatariusza Aktu Niepodległości Litwy ZigmasaVaišvilyz dn. 21 stycznia 2014 r. „W sprawie nowych manewrów GKW w sprawie ogłoszenia referendum”. Apel do Sejmu i członków grupy inicjatywnej ogłoszenia referendum (21 stycznia 2014 r., Nr rejestr. g-2014-797).

${ }^{21}$ „Valstybės žinios” 1994, Nr 94-1852. 
Podczas organizowania referendum w sprawie zakazu sprzedaży ziemi obcokrajowcom wreszcie zwrócono uwagę na inną, nie mniej istotną funkcję Głównej Komisji Wyborczej - funkcję kontrolną, zaś dokładnie - na jej obowiązek w zapewnieniu, by dokumenty dotyczące przeprowadzenia referendum, które do niej zostały złożone przez grupę inicjatywną, a następnie powinny być przekazane Sejmowi, były zgodne z wymogami zawartymi w Ustawie o Referendum. Jest to szczególnie aktualne, gdy się sprawdza, czy podpisy obywateli posiadających czynne prawo wyborcze zostały zebrane w sposób zgodny z prawem.

W analizowanym przypadku Główna Komisja Wyborcza po sprawdzeniu dokumentów złożonych przez grupę inicjatywną w orzeczeniu Nr Sp-39 z dn. 17 lutego 2014 r. „O zgodności z Ustawą Republiki Litewskiej o Referendum dokumentów uzasadniających żądanie obywateli przeprowadzenia referendum"22 potwierdziła nie to, że grupa inicjatywna w sposób należyty zebrała i dostarczyła Głównej Komisji Wyborczej nie mniej niż 300000 podpisów obywateli popierających żądanie przeprowadzenia referendum, a to, że liczba zebranych podpisów dostarczonych Głównej Komisji Wyborczej wynosiła nie mniej niż 300 000. Z punktu widzenia przepisów prawa te sytuacje powinny być oceniane w sposób odmienny.

Podobnego zdania był jeden z koordynatorów grupy inicjatywnej, który zwrócił się do Najwyższego Sądu Administracyjnego Litwy z prośbą o uzupełnienie powyżej wspomnianej decyzji Głównej Komisji Wyborczej, zaznaczając, iż „dostarczone dokumenty są zgodne z Ustawą Republiki Litewskiej o Referendum", ale Najwyższy Sąd Administracyjny Litwy orzekł, że jest to pośrednia decyzja proceduralna niepowodująca żadnych konsekwencji materialnych, która nie może być samodzielnym przedmiotem postępowania administracyjnego i odmówił przyjęcia wniosku koordynatora grupy inicjatywnej ${ }^{23}$.

Jak się okazało później (ironizując, można by rzec, że podczas organizowania i przeprowadzenia referendum w sprawie zakazu sprzedaży ziemi obcokrajowcom, wszystko się wyjaśniło później), Najwyższy Sąd Administracyjny Litwy, wydając orzeczenie w sprawie decyzji Głównej Komisji Wyborczej, na mocy której dokumenty zostały uznane za zgodne z przepisami Ustawy o Referendum i przekazane do Sejmu jako w istocie nominalne, nie miał racji. W ówczesnej redakcji Ustawy o Referendum była zatwierdzona taka regulacja prawna (s. 14), że Sejm po otrzymaniu odpowiednich dokumentów w sprawie referendum i - najważniejsze - pozytywnego wniosku Głównej Komisji Wyborczej w sprawie ich zgodności z Ustawą o Referen-

22 TAR, 2014, Nr 2014-01673.

${ }^{23}$ Postanowienie Najwyższego Sądu Administracyjnego Litwy z dn. 21 lutego 2014 r. w postępowaniu administracyjnym Nr R756-6/2014. 
dum, miał obowiązek ogłoszenia referendum (1 d.) nawet w tym przypadku, gdyby grupa ekspertów powołanych przez Sejm przedstawiła wniosek, że wraz z przedstawionym przez obywateli żądaniem ogłoszenia referendum proponowany tekst jest niezgodny z Konstytucją; wówczas taki wniosek należało ogłosić publicznie, by społeczeństwo mogło się z nim zapoznać (2 d). Czyli faktycznie na tym etapie organizowania referendum właśnie decyzja Sejmu, a nie Głównej Komisji Wyborczej, była wiążąca i faktycznie od Sejmu zależało, jakie z tego wynikną konsekwencje materialne i prawne. Postanowienie Sejmu miało ściśle formalny chrakter ${ }^{24}$.

Nie zważając na przeszkody wskazane powyżej, odpowiednie dokumenty zostały przekazane Sejmowi i na mocy jego uchwały zostało ogłoszone referendum w sprawie zakazu sprzedaży ziemi obcokrajowcom ${ }^{25}$. Wyniki referendum nie były jednak wiążące, ponieważ wzięło w nim udział zaledwie 15\% ogółu wyborców, czyli 380000 obywateli posiadających czynne prawo wyborcze ${ }^{26}$.

${ }^{24}$ Sąd Konstytucyjny Republiki Litewskiej w orzeczeniu z dn. 11 lipca 2014 r. uznał taką regulację prawną za sprzeczną z Konstytucją.

${ }_{25}$ Pismo Głównej Komisji Wyborczej Republiki Litewskiej z dn. 3 marca 2014 r. Nr 2-244(2.10.PI) „W sprawie przekazania dokumentów o referendum w sprawie zmiany art. 9,47 i 147 Ustawy o Konstytucji Republiki Litewskiej; Uchwała Sejmu Republiki Litewskiej $\mathrm{z}$ dn. 10 kwietnia 2014 r. Nr XII-816 „O ogłoszeniu referendum w sprawie zmiany art. 9, 47 i 147 w Konstytucji Republiki Litewskiej”, TAR, 2014, Nr 2014-04281.

${ }^{26}$ Zob. więcej na stronie internetowej GKW: http://www.vrk.lt/2014-referendumas/ (dostęp 10.11.2014). 